Personally, I desire frankly to say, that, as between staying at home at such a time in the cheerful society of my family and friends, and going to a distant city to endure the doubtful comforts of even the best hotel in the town, for the purpose of discussing the best method of combating the San Jose scalebug, of collecting dinosaurs, or discovering the fossil fig-leaf aprons of Adam and Eve in the kitchen middens of Kilat-i-ghiljie, I will elect every time the former alternative, and I think I represent the sentiment of a very large number of gentlemen, who are horiored by membership in the American Association for the Advancement of Science. We do not yield to any of our brethren in our devotion to science, but at the same time we have not yet come to that point where we are willing to sacrifice our known duty to our wives and children for the somewhat vague benefits of attendance upon meetings where at best we shall not learn much. I am told by one of the officers of the late meeting at St. Louis that very few persons were present at the meeting coming from a distance, except those who stood in some official relationship to the body, and who, therefore, felt compelled to be on hand. Those who were present, besides the official membership of the society, largely represented the local constituency. The reason for this is perfectly plain to my mind in view of what I have already stated. If the American Association insists upon meeting in the last week of the dying year the gatherings are likely to reveal moribundity as the years die in succession.

W. J. Holland.

Carnegie Institute,

Pittsburgh, Pa., February 25, 1904.

THE RAPHIDES OF CALCIUM OXALATE.

To the Editor of Science: In your issue of July 24, 1903, I gave a description of a phenomenon observed by Mr. B. J. Howard, of this bureau, showing the collection of the crystals of oxalate of lime in bomb-like cells in certain acrid plants, such as the Indian turnip. I beg to call attention to the fact that Dr. H. A. Weber in the Journal of the American Chemical Society, Vol. 13, No.
7, published some interesting data regarding the cause of acridity in certain plants. As the conclusion of his experiments he stated: 'These experiments show conclusively that the acridity of the Indian turnip and calla is due to the raphides of calcium oxalate only.' Dr. Weber's explanation of the destruction of acridity in certain cases where calcium oxalate crystals are found is interesting. $\mathrm{He}$ ascribes it to the presence of a thick mucilage, or in cases where starch is present and where boiling destroys the acridity he ascribes this loss of acridity to the production of starch paste. The mucilage and the starch paste serve to restrain the activity of the crystals and prevent them from entering the surface of the tongue and mouth.

Mr. Howard has found that the colocasia leaf, which contains but little stäch, retains its acridity when boiled until the acicular crystals are destroyed. The same observation applies to the Indian turnip, which contains a notable percentage of starch. It is probable therefore in all cases that the acridity continues as long as the needle-like crystals are intact. On recrystallization in these cases the lime oxalate assumes the octahedral form and the acridity is not restored. It is only in case the crystals are very fine and sharply pointed that acridity is pronounced. Large and more bluntly pointed crystals produce little or no effect.

Dr. Weber describes also the investigations of Professor W. R. Lazenby on the occurrence of crystals in plants, and states that Professor Lazenby is of the opinion that the acridity of the Indian turnip is due to the presence of the crystals of calcium oxalate. It seems only proper in this connection to call attention to these earlier observations which the experiments described in my letter of the above date fully confirm. H. W. WILEY.

\section{THE TERM 'BRADFORDIAN.'}

To the Editor of Science: On page 24 of the current volume of Science, January 1, 1904, Dr. G. H. Girty is reported as having proposed the term Bradfordian for transition beds between Devonian and Carboniferous. It is not quite clear whether he intends the term 
to denote 'a series of rocks' or an 'interval in the time-scale.' In any case, the name Bradfordian is well known to students of European Mesozoic rocks, having been proposed by Desor in 1859, for Upper Bathonian rocks, as exemplified at Bradford-on-Avon in England. Dr. Girty doubtless overlooked this, although he might have found it in Professor Renevier's valuable 'Chronographe géologique' published by the International Congress of Geologists.

It is always a pity when the names of wellknown European places are applied by geologists to newly established stratigraphical divisions in other countries. Instances of this, both in the British colonies and in the United States of America, are perplexingly numerous. Even such terms as 'Cussewago' and 'Cuyahoga' are to be preferred.

F. A. B.

\section{SPECIAL ARTICLES.}

NOTES ON FLUORESCENCE AND PHOSPHORESCENCE.

THE phosphorescent and fluorescent properties of natural minerals have attracted considerable notice and some highly interesting papers have been recently written on the subject, but artificial products of this class do not appear to have claimed much attention.

It is well known that minerals found in one locality may fluoresce brightly under suitable excitation, while other specimens, apparently similar, but taken from another locality, may be unresponsive under a like excitation.

It is also well known that a minute trace of certain substances, when properly incorporated with a large quantity of another substance, will sometimes impart fluorescent and phosphorescent properties to the latter. For example, if a trace of manganese chloride is fused with sodium chloride, the latter will fluoresce red under ultra-violet light, whereas sodium chloride fused by itself will show no color fluorescence. It, therefore, appears altogether probable that the fluorescent properties of some natural minerals is due to the presence of another substance in minute quantity, and in the absence of this constituent an otherwise similar mineral may be nonfluorescent.

The writer having given some study to the artificial production of fluorescent and phosphorescent compounds, is tempted to present a description of a few simple experiments in the hope that their results may prove interesting to other investigators, and thus lead to further developments in this fascinating field of research.

The ultra-violet light used for testing was made by a small high-tension arc produced by a condenser discharge between two iron balls about one half inch in diameter, the air gap being adjustable and the condenser being charged by an alternating current of 60 cycles and 120 volts, stepped up to about 5,000 volts.

Experiment No. 1.-Zinc sulphate was dissolved in a small quantity of distilled water holding a trace of manganese sulphate in solution. The mixture was boiled to dryness and then calcined at a full red heat in a porcelain crucible for about thirty minutes. The resulting white powder fluoresced a light pink and phosphoresced an intense red, having the appearance of being red hot.

Experiment No. 2.-Zinc chloride was dissolved in a small quantity of distilled water holding a trace of manganese sulphate in solution. An equal quantity by measure of soda silicate of a syrupy consistency was then added and the mixture triturated to a thick cream. It was then dried and calcined at a full red heat in a porcelain crucible for about three hours. The resulting white powder showed a light green fluorescence and phosphoresced brightly the same color.

Experiment No. 3.-Substituting cadmium chloride for zinc chloride, but otherwise using the same ingredients and treatment as described in the last experiment, the resulting white powder fluoresced a light pink and phosphoresced an orange yellow.

Experiment No. 4.-Cadmium sulphate was dissolved in distilled water with a trace of manganese sulphate, evaporated to dryness and calcined at a red heat in a porcelain crucible for fifteen minutes. The resulting powder fluoresced a dull yellow, and phosphoresced a light green. The phosphorescence of 